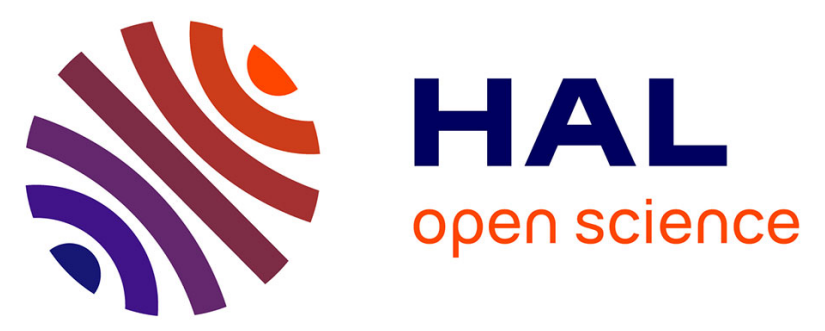

\title{
The crystal structure of the cephalosporin deacetylating enzyme acetyl xylan esterase bound to paraoxon explains the low sensitivity of this serin hydrolase to organophosphate inactivation
}

Silvia Montoro-García, Fernando Gil-Ortiz, Francisco García-Carmona, Luis

Mariano Polo, Vicente Rubio, Alvaro Sánchez-Ferrer

\section{To cite this version:}

Silvia Montoro-García, Fernando Gil-Ortiz, Francisco García-Carmona, Luis Mariano Polo, Vicente Rubio, et al.. The crystal structure of the cephalosporin deacetylating enzyme acetyl xylan esterase bound to paraoxon explains the low sensitivity of this serin hydrolase to organophosphate inactivation. Biochemical Journal, 2011, 436 (2), pp.321-330. 10.1042/BJ20101859 . hal-00592571

\section{HAL Id: hal-00592571 \\ https://hal.science/hal-00592571}

Submitted on 13 May 2011

HAL is a multi-disciplinary open access archive for the deposit and dissemination of scientific research documents, whether they are published or not. The documents may come from teaching and research institutions in France or abroad, or from public or private research centers.
L'archive ouverte pluridisciplinaire HAL, est destinée au dépôt et à la diffusion de documents scientifiques de niveau recherche, publiés ou non, émanant des établissements d'enseignement et de recherche français ou étrangers, des laboratoires publics ou privés. 
The crystal structure of the cephalosporin deacetylating enzyme acetyl xylan esterase bound to paraoxon explains the low sensitivity of this serin hydrolase to organophosphate inactivation

Silvia Montoro-García*§, Fernando Gil-Ortiz ${ }^{\dagger \S}$, Francisco García-Carmona*, Luis Mariano Polo ${ }^{\dagger}$, Vicente Rubio ${ }^{\dagger 1}$, Álvaro Sánchez-Ferrer*¹

*Department of Biochemistry and Molecular Biology-A, Faculty of Biology, University of Murcia, Campus Espinardo, E-30100 Murcia, Spain,

${ }^{\dagger}$ Instituto de Biomedicina de Valencia-Consejo Superior de Investigaciones Científicas (IBV-CSIC) and Centro de Investigación Biomédica en Red de Enfermedades Raras, Valencia, Spain.

${ }^{1}$ Corresponding authors:

Vicente Rubio, E-mail address: rubio@ibv.csic.es

Álvaro Sánchez-Ferrer, E-mail address: alvaro@um.es

${ }^{\S} \mathrm{SMG}$ and FGO contributed equally to this work.

Short title: structure of paraoxon-bound cephalosporin deacetylase/acetyl xylan esterase

Keywords: Bacillus pumilus, diethylphosphate, $\alpha / \beta$ hydrolase, irreversible inhibition, cephalosporin deacetylase.

\section{Abbreviations used:}

AXE/CAH, acetyl xylan esterase/cephalosporin acetyl hydrolase; DEP, diethyl phosphate; DFP, diisopropylfluorophosphate; OP, organophosphorus compound; paraoxon, paraoxon-ethyl, diethyl-p-nitrophenyl phosphate; paraoxon-methyl, dimethylp-nitrophenylphosphate; BpAXE, AXE/CAH from Bacillus pumilus; BpAXE-apo, BpAXE structure without ligands; BpAXE-DEP, BpAXE structure with DEP bound; BsAXE, AXE/CAH from Bacillus subtilis; AeCXE1, carboxylesterase from the plant Actinida eriantha; $p$-NPA, $p$-nitrophenyl acetate.

\section{Protein Databank accession numbers:}

The final models and structure factors for the BpAXE-apo and BpAXE-DEP crystal structures have been deposited in the Protein Databank (http://www.rcsb.org) under codes 2 XLB and 2 XLC respectively. 


\section{SYNOPSIS}

Organophosphorus insecticides and nerve agents irreversibly inhibit serine hydrolase superfamily enzymes. One enzyme of this superfamily, the industrially important (for $\beta$ lactam antibiotic synthesis) acetyl xylan esterase/cephalosporin acetyl hydrolase (AXE/CAH) from the biotechnologically valuable organism Bacillus pumilus, exhibits low sensitivity to the organophosphate paraoxon, reflected in a high $\mathrm{K}_{\mathrm{I}}$ for it $(\sim 5 \mathrm{mM})$ and in a long $t_{1 / 2}(\sim 1 \mathrm{~min})$ for enzyme-paraoxon (E-DEP) covalent adduct formation. The crystal structure of the E-DEP complex determined at $2.7 \AA$-resolution reveals strain in the active Ser ${ }^{181}$-bound organophosphate as a likely cause for the limited paraoxon sensitivity. The strain results from active site size limitation imposed by bulky conserved aromatic residues that may exclude as substrates esters having acyl groups larger than acetate. Interestingly, in the enzyme doughnut-like homohexamer the six active sites are confined within a central chamber formed between two $60^{\circ}$-staggered trimers. The exclusive access to this chamber through a hole around the threefold axis possibly limits the size of the xylane natural substrates. The enzyme provides a rigid scaffold for catalysis, as reflected in the lack of movements associated with paraoxon adduct formation, as revealed by comparing this adduct structure with that determined also here at $1.9 \AA$-resolution for the paraoxon-free enzyme. 


\section{INTRODUCTION}

Organophosphorus compounds (OPs) have been used extensively for decades to control agricultural and household pests, having become an important environmental threat $[1,2]$ with the compound diethyl-p-nitrophenyl-phosphate (paraoxon), the toxic metabolite of the insecticide parathion, being a paradigmatic representative of these compounds [3]. OPs are highly toxic to mammals including man [1,4], and, indeed, they have been used as nerve gases [5]. Their toxicity derives mainly from their ability to irreversibly inactivate the enzyme acetylcholinesterase, which plays a key role in terminating neurotransmission at neuromuscular junctions and in the cholinergic synapses of the nervous system [6]. This inactivation results from the selective formation of a stable covalent adduct between the OP and the highly nucleophilic active center serine belonging to the $\mathrm{Glu} / \mathrm{His} / \mathrm{Ser}$ catalytic triad of acetylcholinesterases [7]. Since the same mechanism is shared by many other enzymes belonging to the $\alpha / \beta$ hydrolase superfamily [8] which use an active centre highly nucleophilic serine as the key catalyst, all these enzymes should be expected in principle to be susceptible to irreversible inhibition by paraoxon and other OPs.

We confirm here this susceptibility for a representative of an enzyme group belonging to this superfamily and having important biotechnological potential, the acetyl xylan esterases/cephalosporin $\mathrm{C}$ deacetylases (AXE/CAHs), which form group 7 among the carbohydrate esterases in the CAZY (http://www.cazy.org) classification of carbohydrate-active enzymes [9]. These enzymes appear to be homohexameric ([10] and discussion therein) and they present unique double specificity, since they catalyze the deacetylation of short acetylated xylooligosaccharides (Figure 1A), participating in the degradation of the xylan plant cell wall component, but they are also cephalosporin $\mathrm{C}$ deacetylases (Figure 1B), removing the acetyl group at the 3-position of cephalosporin $\mathrm{C}$ and of 7-amino cephalosporanic acid (Figure 1C) [10-12]. This latter activity endows AXE/CAHs with industrial interest in the semisynthetic production of $\beta$-lactam antibiotics [11].

In our present studies we have utilized the AXE/CAH from Bacillus pumilus (BpAXE), an industrially highly value organism used for the production of alkaline proteases [13], for the environmental decontamination of dioxins [14], in the baking industry [15], and as a pesticide because strain GB 34 (006493) protects soybean roots against certain fungi (www.epa.gov/oppbppd1/biopesticides/ingredients/factsheets/factsheet_006493.htm). We prove here that BpAXE is completely inhibited by paraoxon, but we also find by analyzing the paraoxon inhibition kinetics [16] that this enzyme has a high $\mathrm{K}_{\mathrm{I}}$ for this OP and that the collapse of the non-covalent complex with the inhibitor to the irreversible adduct is slow. These findings indicate that the paraoxon sensitivity of this enzyme is low compared to those of acetylcholinesterases [17] and carboxylesterases [18], the classical enzymes on which the effects of paraoxon were characterized.

Previously, one enzyme of the serine hydrolase superfamily, the D-type esterase S-formylglutathione hydrolase, was proven to be paraoxon-insensitive because of the presence of a tryptophan blocking access of paraoxon to the catalytic serine [19]. However, the alignment with D-type esterases failed to reveal such tryptophan in AXE/CAHs (not shown). To try to understand the reduced sensitivity of BpAXE to paraoxon we have determined the crystal structure at 2.7 $\AA$-resolution of BpAXE in the presence of this OP. This structure, together with that of paraoxon-free BpAXE at 1.9 Å-resolution, are reported presently, revealing a doughnut-like homohexameric point 32 architecture formed by two $60^{\circ}$-staggered trimers in which the subunits present a 
modification of the classical $\alpha / \beta$ hydrolase fold [8]. The structure obtained in the presence of paraoxon allows rationalization of the decreased paraoxon sensitivity of BpAXE, since although each enzyme subunit is found to host one diethylphosphate (DEP) molecule covalently bound to the active site Ser, there is evidence of steric hindrance to accommodating the DEP. The conservation of the residues causing this steric hindrance indicates that AXE/CAHs from other organisms should exhibit similarly low paraoxon sensitivity. The comparison of the structures of the ligand-free and DEP-containing structures reveals lack of significant conformational changes upon paraoxon binding and catalysis, indicating that AXE/CAHs are highly rigid catalysts that might offer a favorable case for trying to devise industrially interesting artificial chemical catalysts resembling these enzymes.

\section{EXPERIMENTAL}

\section{Enzyme purification}

PCR-amplification of the AXE gene from genomic DNA of $B$. pumilus strain CECT5072 using primers derived from the B. pumilus PS213 AXE gene sequence (GenBank accession number AJ249957) [20], its cloning into pET28a (from Novagene) and the production of the protein (containing a 36-residue N-terminal extension hosting a 6-His tag) from this plasmid in Escherichia coli Rosetta (DE3) pLys cells have been reported [12]. For large scale enzyme production the cells were grown with aeration at $37^{\circ} \mathrm{C}$, to $\mathrm{OD}^{600}=1.6-1.8$, in four litres of Terrific Broth containing $50 \mu \mathrm{g} \cdot \mathrm{ml}^{-1}$ kanamycin and $34 \mu \mathrm{g} \cdot \mathrm{ml}^{-1}$ chloramphenicol. Induction was carried out with $0.5 \mathrm{mM}$ isopropyl- $\beta$-D1-thiogalactopyranoside for 14 hours at $30^{\circ} \mathrm{C}$. Unless indicated, subsequent steps were at $22^{\circ} \mathrm{C}$. The cells, collected by centrifugation $(6000 \mathrm{~g}, 15 \mathrm{~min})$ and suspended in one litre of $0.05 \mathrm{M}$ Tris-HCl, $\mathrm{pH} 8.0$, were broken in a mill homogenizer (Minizeta IIE, Neztch, Germany), the homogenate was centrifuged again, the supernatant was incubated $30 \mathrm{~min}$ with $3 \mathrm{U} / \mathrm{ml}$ DNAase I (from Sigma) and was centrifuged once more before 5-fold concentration by ultrafiltration through a $100 \mathrm{kDa}$-cutoff membrane (QuixStand System, GE Healthcare), prior to application to three $5 \mathrm{ml}$ HiTrapCaptoQ columns placed in series in an AktaPrime Plus Purifier (GE Healthcare) which had been equilibrated with $0.05 \mathrm{M}$ Tris- $\mathrm{HCl}, \mathrm{pH} 8.0$. After washing with a $100 \mathrm{ml}$ linear gradient of $0-0.25 \mathrm{M} \mathrm{NaCl}$, the enzyme was eluted isocratically with $300 \mathrm{ml}$ of the $0.25 \mathrm{M} \mathrm{NaCl}$ solution. Pooled enzyme-containing fractions were applied to a 5-ml HisTrap FF column (GE Healthcare) equilibrated and washed with $0.05 \mathrm{M}$ Tris-HCl, $\mathrm{pH} 8.0,5 \mathrm{mM}$ imidazole, $0.5 \mathrm{M} \mathrm{NaCl}$, eluting the enzyme with a $200 \mathrm{ml}$ linear imidazole gradient (to $0.5 \mathrm{M}$ imidazole). Pure AXE (monitored by SDS-PAGE) was eluted at 0.04-0.06 M imidazole. It was freed from imidazole using HiTrap Desalting columns (GE Healthcare), concentrated to $5-10 \mathrm{mg} / \mathrm{ml}$ by centrifugal ultrafiltration $(100 \mathrm{kDa}$ filter devices from Amicon) and stored at $-80^{\circ} \mathrm{C}$.

\section{Enzyme activity assay and determination of kinetic parameters for p-NPA and paraoxon}

Enzyme activity was determined by following continuously $p$-nitrophenyl acetate ( $p$ NPA) hydrolysis at $405 \mathrm{~nm}\left(\varepsilon_{405 \mathrm{~nm}}\right.$ for $p$-nitrophenol at $\left.\mathrm{pH} 7.0,6225 \mathrm{M}^{-1} \mathrm{~cm}^{-1}\right)$ in a solution containing $0.01 \mathrm{M} \mathrm{K}$ phosphate, $\mathrm{pH} 7.0$, and $p$-NPA at a concentration of either $2 \mathrm{mM}$ (standard assay) or in the $0-15 \mathrm{mM}$ range (when determining $\mathrm{K}_{\mathrm{m}}$ and $\mathrm{V}_{\max }$ values). Non-enzymatic $p$-NPA hydrolysis was negligible. Dependency of the velocity versus the concentration of $p$-NPA was hyperbolic. Inhibition by organophosphates was 
analyzed by following continuously $p$-NPA hydrolysis after adding the enzyme to the assay solution containing $2 \mathrm{mM} p$-NPA and either $20 \mathrm{mM}$ diisopropylfluorophosphate (DFP) or $0-20 \mathrm{mM}$ paraoxon-methyl or $0-8 \mathrm{mM}$ paraoxon (upper concentration limits set by solubility). The amount of enzyme added in these assays was proportional to that of paraoxon $\left(0.028 \mu \mathrm{g} \mathrm{ml}^{-1} \mathrm{mM}^{-1}\right.$ of paraoxon).

Equations 1-3 apply to a competitive irreversible inhibitor (Figure 2A) [21-24] and were used to analyze organophosphate inhibition from reaction progress curves:

Equation 1: $\quad\left[\mathrm{P}_{\infty}\right]=\mathrm{k}_{2} \mathrm{~K}_{\mathrm{I}}^{\text {app }}[\mathrm{S}][\mathrm{E}] /\left(\mathrm{k}_{\mathrm{i}} \mathrm{K}_{\mathrm{m}}[\mathrm{I}]\right)$

Equation 2: $\quad\left[\mathrm{P}_{\mathrm{t}}\right]=\left[\mathrm{P}_{\infty}\right]\left(1-\mathrm{e}^{-\lambda t}\right)$

Equation 3: $\quad \lambda=\mathrm{k}_{\mathrm{i}}[\mathrm{I}] /\left(\mathrm{K}_{\mathrm{I}}^{\text {app }}\left(1+\left([\mathrm{S}] / \mathrm{K}_{\mathrm{m}}\right)\right)+[\mathrm{I}]\right)$

$[\mathrm{E}],[\mathrm{S}]$ and $[\mathrm{I}]$ are the concentrations of enzyme, substrate and inhibitor, $\left[\mathrm{P}_{\mathrm{t}}\right]$ and $\left[\mathrm{P}_{\infty}\right]$ are the concentrations of product formed at time $t$ and at infinite time; $\lambda$, apparent firstorder constant for product accumulation; $\mathrm{k}_{2}$, first-order rate constant for enzymesubstrate complex collapse to products; $\mathrm{K}_{\mathrm{I}}{ }^{\mathrm{app}}$, Michaelis-type constant for the reversible enzyme-inhibitor complex; $\mathrm{k}_{\mathrm{i}}$, first-order rate constant for collapse of the reversible enzyme-inhibitor complex to the covalent adduct; $\mathrm{K}_{\mathrm{m}}$, constant of Michaelis. From Eq. 1 $\left[\mathrm{P}_{\infty}\right]$ should have identical values irrespective of the enzyme concentration if the $[\mathrm{E}] /[\mathrm{I}]$ ratio is kept constant [16]. Plots of $\lambda$ (determined from progress curves using Eq.2) versus the concentration of organophosphate were hyperbolic as demanded by Eq.3 and allowed determination of $\mathrm{k}_{\mathrm{i}}$ (value of $\lambda$ at [paraxon] $=\infty$ ) and $\mathrm{K}_{\mathrm{I}}^{\text {app }}$ since $[\mathrm{S}$ ] was $2 \mathrm{mM}$ and the $\mathrm{K}_{\mathrm{m}}$ (for $p$-NPA) was determined independently from substrate-velocity studies. Curve fitting was carried out with GraphPad Prism (GraphPad Software Inc, La Jolla, California).

\section{Crystallization and data collection}

The sparse matrix vapour diffusion sampling procedure [25] was used for screening crystallization conditions at $21^{\circ} \mathrm{C}$ in sitting drops of $0.4 \mu \mathrm{l}$ reservoir fluid and $0.4 \mu \mathrm{l}$ of $8 \mathrm{mg} / \mathrm{ml} \mathrm{BpAXE}$ in $0.05 \mathrm{M}$ Tris $/ \mathrm{HCl}, \mathrm{pH} 8.0$, alone or supplemented with 0.5 $\mathrm{mM}$ paraoxon. The best BpAXE crystals prepared in the absence of ligands (BpAXEapo) ( $\sim 0.3 \mathrm{~mm}$ largest dimension) were obtained using as crystallization solution $0.2 \mathrm{M}$ $\mathrm{MgCl}_{2}, 0.1 \mathrm{M}$ Hepes, $\mathrm{pH} 7.5,30 \%$ (w/v) PEG [poly(ethylene glycol)] 400. The best BpAXE crystals prepared in the presence of paraoxon (BpAXE-DEP) (cubic, $0.2 \mathrm{~mm}$ maximal dimension) grew using as crystallization solution $0.2 \mathrm{M}$ ammonium acetate, $0.1 \mathrm{M}$ Bistris, $\mathrm{pH} 5.5,45 \%$ 2-methyl-2,4-pentanediol. Crystals frozen directly from the drop were diffracted at $100 \mathrm{~K}$ (Oxford cryosystems) at the ESRF synchrotron (Grenoble), using beamline ID23-1 and an ADSC Quantum 315r CCD detector (BpAXE-apo), or beamline BM16 and an ADSC Quantum 210r CCD detector (BpAXE-DEP), yielding respective datasets at 1.9 and $2.7 \AA$ resolution. Data processed with MOSFLM, SCALA and TRUNCATE [26] (Table 1) revealed monoclinic cells (space group P $2_{1}$ ) of different dimensions (Table 1) which contained in the asymmetric unit (see below) two and one enzyme homohexamers, respectively, with $48 \%$ and $45 \%$ solvent contents.

\section{Structure Solution and Refinement}

Phases were determined by molecular replacement with MOLREP [27] using as search model for BpAXE-apo one subunit of the Bacillus subtilis AXE (BsAXE) [Protein Databank (PDB) code 1ODS] devoid of ligands and water molecules. The structure obtained in this way (see below) of the BpAXE-apo hexamer was used for molecular replacement in the BpAXE-DEP crystal. The solutions consisted of 12 chains forming 2 hexamers (BpAXE-apo) or 6 chains forming one hexamer (BpAXE-DEP) in 
the asymmetric unit. Rigid body refinement was performed stepwise with increased resolution, and it was followed by automated refinement using program REFMAC [26] alternating with graphic manual model adjustment sessions with program COOT [28]. Initial phases were improved by density modification using histogram matching, solvent flattening and density averaging as implemented in program DM [26]. Electron density from the resulting difference maps was interpreted, and a model of the protein was constructed except for the three C-terminal residues in both structures and for residues 1-7 of the BpAXE-DEP. B-factors and positional non-crystallographic symmetry restraints were used and gradually released as refinement progressed. All the diffraction data were used throughout the refinement process except the $5 \%$ randomly selected data for calculating $\mathrm{R}_{\text {free. }}$. Crystal twinning was detected in the BpAXE-apo crystal (twin fraction 0.46), being refined as the BpAXE-DEP but including the twinning correction option available in REFMAC5 (v5.5.088). TLS was applied in the last steps of refinement with the TLSMD server for definition of the TLS groups [29]. The final models at $1.9 \AA$ (BpAXE-apo) or $2.7 \AA$ (BpAXE-DEP) resolution exhibited excellent $\mathrm{R}_{\text {factor }} / \mathrm{R}_{\text {free }}$ values (Table 1 ), and included two hexamers (residues 1 to 317 in each subunit) (BpAXE-apo) or one hexamer (residues 7-317) (BpAXE-DEP) in the asymmetric unit. In the case of the BpAXE-DEP crystal, non-protein electron density was found in the active centre of each subunit, which fitted best bound DEP. Structure analysis with PROCHECK yielded excellent stereochemistry for both models (Table 1) [30].

Superposition of structures and rmsd calculation were carried out with the SSM option of program COOT [28] using default parameters. Figures were drawn using program PyMOL (http://pymol.sourceforge.net/) [31].

\section{Other methods}

Protein was determined by the method of Bradford [32] using bovine serum albumin as the standard. SDS-PAGE was performed in $12 \%$ polyacrylamide gels, followed by coomassie staining. Analytical gel filtration chromatography was carried out as reported previously [33], using a Superdex 200 (10/300) column mounted on an AKTA FPLC system (GE Life Sciences). The column was equilibrated and run at $24^{\circ} \mathrm{C}$ with a solution of $0.05 \mathrm{M}$ Tris $/ \mathrm{HCl}, \mathrm{pH} 7.5$, and $0.15 \mathrm{M} \mathrm{NaCl}$. A semilogarithmic plot of the molecular masses of marker proteins (Sigma) versus the distribution coefficient $\left(K_{d}\right)$ for each protein was used for estimating the mass of BpAXE. $K_{d}$ values were calculated from the expression $K_{d}=(V e-V o) /(V i-V o)$, where $V o, V i$, and $V e$ are the elution volumes of dextran blue, water (estimated by monitoring conductivity), and the protein of interest, respectively.

\section{RESULTS AND DISCUSSION}

\section{Characteristics of BpAXE and irreversible inhibition by paraoxon.}

Sequence comparisons [10], molecular mass estimates (Figure 2B) and enzyme activity assays [12] prove that BpAXE is a typical AXE/CAH. The gene for this enzyme (see Materials and Methods) encodes a polypeptide chain having essentially the same length (320 residues) as, and $41 \%, 76 \%$ and $89 \%$ sequence identity with, the AXE/CAHs from Thermotoga maritima, B. subtilis and B. pumilus strain P213, respectively [10]. As expected from members of group 7 of the carbohydrate esterase family (CE-7), all these enzymes present the CE-7 family "signature" [10] which consists of three strictly conserved sequence motifs: RGQ, GxSQG (which hosts the catalytic serine) and HE (which hosts the histidine of the catalytic triad). Concerning 
oligomeric structure, BpAXE is hexameric, both in solution, as indicated by size exclusion chromatography results (Figure 2B) obtained over a very large range of enzyme concentrations (1.8 $\mathrm{nM}$ to $36 \mu \mathrm{M}$ ) (small panel in Figure 2B), and in crystalline form (see below). This is characteristic of AXE/CAHs, as proven structurally also for BsAXE [10]. Finally, the enzyme from B. pumillus catalyzed the deacetylation of acetylxylan, 7-amino-3-deacetylcephalosporanic acid and cephalosporin C (Figures 1B and $1 \mathrm{C})$ [12]. Its high activity with the artificial substrate $p$-NPA $\left(\mathrm{K}_{\mathrm{m}}\right.$ and $\mathrm{V}_{\max }$ values, determined here at $25^{\circ} \mathrm{C}$, are, respectively, $1.6 \pm 0.5 \mathrm{mM}$ and $16.5 \pm 0.2 \mathrm{U} / \mathrm{mg}$ ), which is also a characteristic of AXEs (Figure 1D) as described for BsAXE [10], has been exploited here for assaying enzyme activity by following continuously the production of the colored product, $p$-nitrophenol.

Addition of BpAXE to a solution containing both $p$-NPA and paraoxon resulted in fast initial production of $p$-NPA (monitored by the rapid colour increase) which progressively decreased with time until it stopped completely (Figure 2C). The final amount of colour obtained (Figure 2C) indicates that, at the $1.18 \times 10^{-7}$ enzyme hexamer/paraoxon molar ratio used, only $8 \%$ of the $p$-NPA was hydrolyzed, excluding that substrate depletion accounted for the observed decrease with time in the reaction rate. The presence of abundant substrate after the reaction had stopped was confirmed by adding a second enzyme sample: the reaction re-started again and gradually declined again until it was stopped, as with the first addition (data not shown). This gradually decreasing rate of product release is typical of irreversible inhibitors [21], reflecting the time taken for reaction of the enzyme molecules with the inhibitor [22].

\section{BpAXE exhibits low sensitivity to paraoxon.}

Figure $2 \mathrm{C}$ demonstrates for BpAXE that product accumulation in the presence of paraoxon increases according to an exponential having the form of equation 2 (see Experimental section). Under the conditions used of constant substrate concentration and $[E] /[\mathrm{I}]$ ratio, the amount of product accumulated $\left(\mathrm{P}_{\infty}\right)$ when the inhibition was complete was the same for the different paraoxon concentrations used. This is the expected behavior (see equation 1 in the Experimental section) for an irreversible inhibitor that competes with the substrate [16]. Also as expected for this type of inhibition (equations 1 and 3), the time to reach complete inhibition decreased as the concentrations of inhibitor and enzyme were increased (Figure 2C), and the value of the first-order rate constant for product accumulation ( $\lambda$ of equation 1$)$ depended hyperbolically on the concentration of paraoxon (inset of Figure 2C). The latter plot allowed estimation of values for $\mathrm{K}_{\mathrm{I}}^{\text {app }}$ and $\mathrm{k}_{\mathrm{i}}$ for paraoxon of $\sim 5.4 \mathrm{mM}$ and $0.012 \mathrm{~s}^{-1}$, respectively (for $2 \mathrm{mM} p$-NPA in the assay and a $\mathrm{K}_{\mathrm{m}}$ for $p$-NPA of $1.64 \mathrm{mM}$ ). These $\mathrm{K}_{\mathrm{I}}{ }^{\text {app }}$ and $k_{i}$ values are -30 -fold higher and lower, respectively, than those reported for the acetylcholinesterase from electric eel [17], and they are also much poorer than those reported for the carboxylesterase EST2 from Alicyclobacillus acidocaldarius [18], indicating that BpAXE is much less sensitive to paraoxon than these other enzymes.

\section{Structure of BPAXE}

To investigate the reasons for the low paraoxon sensitivity of BpAXE and to determine whether the bound inhibitor triggers conformational changes, BpAXE crystals were prepared in the absence of ligands (BpAXE-apo) or in the presence of paraoxon (BpAXE-DEP). The structures of these crystalline enzyme forms were determined (see Materials and Methods) at respective resolutions of $1.9 \AA$ and $2.7 \AA$, with excellent quality control indicators (Table 1). They corresponded to doughnut-like homohexamers that can be described as a dimer of two trimers having their threefold 
axes aligned, but which are staggered by $60^{\circ}$ (Figure $3 \mathrm{~A}$ and $3 \mathrm{~B}$ ). Each subunit contacts extensively two subunits of the other trimer, burying surfaces (determined with a probe of $1.4 \AA$ diameter) of $841 \AA^{2}$ in one subunit and $1196 \AA^{2}$ in the other subunit and also making less extensive contacts (buried surfaces, 449 and $272 \AA^{2}$ ) with the other two subunits of the same trimer. Both the apo and the DEP-containing structures replicate closely the reported structure of BsAXE (1ODS) (rmsd values of 0.38 and $0.41 \AA$ for superimposition of 317 and $311 \mathrm{C} \alpha$ atoms, respectively). The subunits fold differs from the canonical $\alpha / \beta$ hydrolase fold in the presence of an extra 3-helix bundle (between $\alpha 6$ and $\beta 8$; green in Figure 3C), as well as the presence of a second insertion consisting of two $\alpha$-helices and a $\beta$ strand at the $\mathrm{N}$-terminus (in blue in Figure 3C) [10]. The 3-helix bundle insertion may play a key role in hexamer formation, since it interacts with one subunit of the adjacent trimer and with another from the same trimer (Figure 3B, helices shown in ribbon representation), in this latter case contacting the loop preceding the $\mathrm{C}$ terminal $\alpha$ helix ( $\alpha 11$ ), which hosts the crucial His298 of the catalytic triad. This interaction, and thus trimer formation, may be important for stabilizing the active centre and the nearby substrate gorge [10], which involves the loop preceding $\alpha 11$ and the beginning of this helix. The hexameric nature of this enzyme may be related to the need to limit the substrate size [10], since the six active centres are confined within a central chamber (Figure 3D) which can be accessed through a central opening (Figure 3B). In agreement with the strong preference of $\mathrm{AXE} / \mathrm{CAHs}$ for relatively small substrates, the catalytic triad $\left(\mathrm{Asp}^{269} / \mathrm{His}^{298} / \mathrm{Ser}^{181}\right.$; Figures $4 \mathrm{~A}$ and $\left.4 \mathrm{~B}\right)$, is within the central chamber. Interestingly, $\mathrm{Arg}^{87}$ and $\mathrm{Gly}^{98}$, belonging to the substrate gorge (Figure $4 \mathrm{~A}$ ) replace $\mathrm{Lys}^{87}$ and $\mathrm{Glu}^{98}$ of BsAXE, perhaps in relation to the lower $\mathrm{K}_{\mathrm{m}}$ for $p$-NPA of BsAXE $(0.29 \mathrm{mM})[10]$ than of BpAXE (1.64 mM, see above).

\section{The structure of the covalent adduct with DEP explains the low sensitivity to this organophosphate and provides clues on how these enzymes select for the size of the acyl substituent to be removed}

Electron density maps (Figure 4B) of the crystal grown in the presence of paraoxon revealed a large mass of density that is continuous with that of the $\operatorname{Ser}^{181} \mathrm{O} \gamma$ and which fits a DEP group, the moiety of paraoxon that would be expected to bind covalently to the catalytic serine following the oxyanion attack by the catalytic serine with release of the $p$-nitrophenyl moiety. The position of the DEP is similar but not identical to that of the DEP found in the active centre of the plant carboxylesterase AeCXE1 [34] (Figure 4C). However, in BpAXE the DEP is encased between the main chain of $\mathrm{Tyr}^{91}$, the catalytic triad residue $\mathrm{His}^{289}$, and the phenolic ring of $\mathrm{Tyr}^{206}$ that lies on a crowded hydrophobic cushion formed by $\mathrm{Tyr}^{222}, \mathrm{Phe}^{210}$ and $\mathrm{Leu}^{207}$ and that thus cannot recede away from DEP (Figure 4B and 4D). Thus, the bound DEP is too close to $\mathrm{Tyr}^{206}$, the $\mathrm{N}$ atom of $\mathrm{Tyr}^{91}$ and $\mathrm{His}^{298}$ and there is some conformational strain in the adduct formed, given the value of $100^{\circ}$ observed for the P-O-C $\mathrm{C}_{\text {Ser }}$ angle at the Serphosphate bridge (Figure 4B), instead of an ideal angle near $110^{\circ}$. This steric hindering and somewhat strained geometry could hamper the binding and may make difficult the reaction of paraoxon with the oxyanion in $\mathrm{Ser}^{181}$, explaining the high $\mathrm{K}_{\mathrm{I}}{ }^{\text {app }}$ and low $\mathrm{k}_{\mathrm{i}}$ of BpAXE for paraoxon. This interpretation is supported by the observations that the smaller organophosphate paraoxon-methyl inactivates the enzyme with much more favourable constants than paraoxon(-ethyl) $\left(\mathrm{K}_{\mathrm{I}}^{\text {app }}\right.$ for one and the other, $13.4 \mu \mathrm{M}$ and $\sim 5.4 \mathrm{mM}$, respectively; and respective $\mathrm{k}_{\mathrm{i}}$ values, 0.279 and $0.012 \mathrm{~s}^{-1}$, Figure $2 \mathrm{D}$ and inset therein), whereas the larger organophosphate diisopropyl fluorophosphate fails to inactivate BpAXE even at a concentration of $20 \mathrm{mM}$ (Figure 2D). 
Given the conservation of $\mathrm{Tyr}^{91}$, $\mathrm{Tyr}^{206}$ and of the hydrophobic cushion on which $\mathrm{Tyr}^{206}$ sits in all AXE/CAHs [10], and also given the very good superimposition (data not shown) of the structures of the active centres of BpAXE, BsAXE, and of the deposited (but not published) structure of the AXE/CAH from Thermotoga maritima (PDB code 3M81), it is clear that the structurally hampered fitting and strained adduct conformation should be constant features of paraoxon binding to all AXE/CAHs, predicting for all these enzymes poor sensitivity to this organophosphate. In contrast, as already indicated, no such structural hampering and conformational strain are observed with the DEP adduct observed in the structure of AeCXE1 [34], a carboxylesterase in which $\mathrm{Tyr}^{91}$ and $\mathrm{Tyr}^{206}$ are replaced by glycines and where there is no obvious hydrophobic cushion blocking this part of the active centre (Figure 4C). In the superimposition of the active centre of this enzyme with BpAXE (Figure 4C) the bound DEP has moved an average value of $1.4 \AA$ away from the main chain of Gly ${ }^{92}$ (corresponding to $\mathrm{Tyr}^{91}$ of BpAXE), invading the position that would be occupied in BpAXE by the phenolic ring of Tyr ${ }^{206}$ but which is accessible in AeCXE1 because of the lack of a side-chain in Gly ${ }^{92}$, thus permitting unstrained DEP binding with optimal geometry (Figure 4C). Correspondingly, the sensitivity of this enzyme to paraoxon should be higher than in the case of BpAXE, in line with the observations with the carboxylesterase EST2 [18].

The strained DEP binding to BpAXE reflects the fact that the active centre of BpAXE, and in general of AXE/CAHs, appears to have evolved for selecting against substrates carrying acyl groups larger than the acetyl substituent $[10,35,36]$. The presence in BpAXE of $\mathrm{Tyr}^{206}$ and of the hydrophobic cushion blocks the active site around Ser ${ }^{181}$, leaving enough space for accommodating an acetyl group but preventing the accommodation of larger substituents such as a butyryl group. Correspondingly, the binding of the larger phosphate group in paraoxon should also be hampered (Figure 5B). In fact, no activity was detected with BpAXE towards $2 \mathrm{mM}$-nitrophenyl butyrate, in line with the preference of AXEs for acetylated substrates [10,35-37]. The importance of the steric obliteration of the site for conferring acyl group specificity is highlighted by the comparison with AeCXE1, which uses most efficiently substrates with a butyryl group substituent [34] and which has no $\mathrm{Tyr}^{206}$ or hydrophobic cushion blocking the active site, which thus is large enough to accommodate a butyryl substituent (Figure 5C). Another example illustrating the importance of active site steric restriction for conferring specificity for the acyl group to be removed is provided by Sformylglutathione hydrolase, an esterase which removes the very small formyl group from its substrate $[19,38]$. In this case the blocking of the active centre is more drastic than for AXE/CAHs, since a bulky tryptophan sitting next to the active centre serine allows reaction with a formyl group but precludes access of larger substituents, thus rendering the enzyme totally insensitive to organophosphates because of the large size of the phosphate (Figure 5A) [19,38].

\section{Two snapshots of DEP interaction possibly mimic different stages of catalysis.}

DEP binding is not identical in the six subunits of BpAXE-DEP (Figure 5D), since the non-bridging $\mathrm{O}$ atom of DEP makes similarly strong hydrogen bonds with the main-chain $\mathrm{N}$ atoms of conserved $\mathrm{Tyr}^{91}$ and $\mathrm{Gln}^{182}$ (respective O-N distances, 2.7 and $2.6 \AA$ ) in subunits A, C and D, but not in subunits B, E and F, where the bond is much stronger with the Tyr than with the Gln (O-N distances, $\sim 2.4 \AA$ and $\geq 3.1 \AA$, respectively) (Figure 5D), existing important intervening electron density between the $\mathrm{O}$ atom and the $\mathrm{Tyr}^{91} \mathrm{~N}$ atom (Figure 4B). Since only in these last subunits $\mathrm{His}^{298}$ is at interaction distance from the $\operatorname{Ser}^{181} \mathrm{O} \gamma$, there may be a functional linkage between the 
short DEP-Tyr91 and His298-Ser181 distances, and these slightly different structures of the DEP site might mimic different stages of this enzyme reactional cycle.

\section{BpAXE appears to be a mechanically rigid catalytic device.}

The BpAXE-apo and BpAXE-DEP structures are virtually identical, as revealed by their superimposition both at the level of individual units ( $r m s d$ of $0.20 \AA$ for $311 \mathrm{C} \alpha$ atoms) or as complete hexamers (rmsd of $0.35 \AA$ for $1866 \mathrm{C} \alpha$ atoms) (Figure $5 \mathrm{E}$ ). This similarity extends to the disposition of the active centre residues, excepting slight movements of less than $1 \AA$ of amino acid side chains around the tetrahedral covalent intermediate in the BpAXE structure (Figure 4E). Clearly, the binding of paraoxon and the generation of the covalent adduct does not induce any conformational change, strongly suggesting that substrate binding and catalysis by BpAXE does not involve important movements on the enzyme. Thus, given our detailed structural and chemical information on these enzymes derived from the present study and from other studies [10], and since AXE/CAHs appear to be rigid size-selecting solid catalytic devices resembling in this respect the zeolytic catalysers used in the chemical industry [39], they may be ideal subjects for trying to re-create them artificially on zeolytic sizing substrates. This possibility would have practical interest derived from the industrial potential of these enzymes for making antibiotics [11].

\section{AUTHORS CONTRIBUTION}

SMG generated constructs, produced the protein, studied the paraoxon inhibition kinetics, and, together with FGO, carried out crystallization trials. FGO collected X-ray data, analyzed them together with LMP, built the model and, together with VR, carried out the analysis and interpretation of the structural data. FGC provided theoretical input and critical advice about the BpAXE inhibition kinetics. VR and ASF directed the work, analyzed the results and, together with FGO and SMG, wrote the paper.

\section{ACKNOWLEDGEMENTS}

We thank the ESRF synchrotron staff for data collection assistance and the EU and EMBL for funding synchrotron visits.

\section{FUNDING}

Supported by grants MEC (BIO2007-62510), "Programa de Ayuda a Grupos de Excelencia de la Región de Murcia", de la Fundación Séneca (Plan Regional de Ciencia y Tecnología 2007/2010), BFU2008-05021 of the Spanish Ministry for Science (MICINN) and Prometeo/2009/051 of the Valencian Government. SMG had a FPU predoctoral research grant from Fundación Séneca, and FGO and LMP were CSICJAE-Doc and CSIC-Banco de Santander predoc fellows, respectively.

\section{REFERENCES}

1. WHO. IPCS-INTOX Databank. Organophophorus insecticides: a general introduction (EHC 63, 1986) http://www.wpro.who.int/NR/rdonlyres/FC89617A1DB8-4AB6-82AD-75197CC7D67C/0/Organophosphorouspesticides.pdf

2. Kamel, F. and Hoppin, J. A. (2004) Association of pesticide exposure with neurologic dysfunction and disease. Environ. Health Perspect. 112, 950-958.

3. Lorke, D. E. and Petroianu, G. A. (2009) Minireview: does in-vitro testing of oximes help predict their in-vivo action after paraoxon exposure? J. Appl. Toxicol. 29, 459469. 
4. Eddleston, M., Singh, S. and Buckley, N. (2005) Organophosphorus poisoning (acute). Clin. Evid. 13, 1744-1755.

5. Newmark, J. (2004) The birth of nerve agent warfare: lessons from Syed Abbas Foroutan. Neurology 62,1590-1596.

6. Bajgar, J. (2004) Organophosphates/nerve agent poisoning: mechanism of action, diagnosis, prophylaxis, and treatment. Adv. Clin. Chem. 38, 151-216.

7. Millard, C.B., Kryger, G., Ordentlich, A., Greenblatt, H.M., Harel, M., Raves, M.L., Segall, Y., Barak, D., Shafferman, A., Silman, I. and Sussman, J.L. (1999) Crystal structures of aged phosphonylated acetylcholinesterase: nerve agent reaction products at the atomic level. Biochemistry 38, 7032-7039.

8. Carr, P. D. and Ollis, D. L. (2009) Alpha/beta hydrolase fold: an update. Protein Pept. Lett. 16, 1137-1148.

9. Coutinho, P. M. and Henrissat, B. (1999) Carbohydrate-active enzymes: An integrated database approach. In: Gilbert, H.J., Davies, G., Henrissat, B. and Svensson, B. pp. 3-12, Recent Advances in Carbohydrate Bioengineering, Royal Society of Chemistry, Cambridge. http://afmb.cnrs-mrs.fr/ pedro/CAZY/db.html.

10. Vincent, F., Charnock, S. J., Verschueren, K. H., Turkenburg, J. P., Scott, D. J., Offen, W. A., Roberts, S., Pell, G., Gilbert, H.J., Davies, G.J. and Brannigan, J.A. (2003) Multifunctional xylooligosaccharide/cephalosporin C deacetylase revealed by the hexameric structure of the Bacillus subtilis enzyme at $1.9 \AA$ resolution. J. Mol. Biol. 330, 593-606.

11. Mitsushima, K., Takimoto, A., Sonoyama, T. and Yagi, S. (1995) Gene cloning, nucleotide sequence, and expression of a cephalosporin-C deacetylase from Bacillus subtilis. Appl. Environ. Microbiol. 61, 2224-2229.

12. Martínez-Martínez, I., Montoro-García, S., Lozada-Ramírez, J. D., Sánchez-Ferrer, A. and García-Carmona, F. (2007) A colorimetric assay for the determination of acetyl xylan esterase or cephalosporin $\mathrm{C}$ acetyl esterase activities using 7-amino cephalosporanic acid, cephalosporin $\mathrm{C}$, or acetylated xylan as substrate. Anal. Biochem. 369, 210-217.

13. Wang, H. Y., Liu, D. M., Liu, Y., Cheng, C. F., Ma, Q. Y., Huang, Q. and Zhang, Y. Z. (2007) Screening and mutagenesis of a novel Bacillus pumilus strain producing alkaline protease for dehairing. Lett. Appl. Microbiol. 44, 1-6.

14. Choi, S. D., Hong, H. B. and Chang, Y. S. (2003) Adsorption of halogenated aromatic pollutants by a protein released from Bacillus pumilus. Water Res. 37, 4004-4010.

15. Nuyens, F., Van Zyl, W. H., Iserentant, D., Verachtert, H. and Michiels, C. (2001) Heterologous expression of the Bacillus pumilus endo-beta-xylanase (xynA) gene in the yeast Saccharomyces cerevisiae. Appl. Microbiol. Biotechnol. 56, 431-434.

16. Tudela, J., García-Canovas, F., García-Carmona, F., Iborra, J. L. and Lozano, J. A. (1986) Irreversible inhibition of Trypsin by TLCK. A continuous method for kinetic study of irreversible enzymatic inhibitors in the presence of substrate. Int. J. Biochem. 18, 285-288.

17. Forsberg, A. and Puu, G. (1984) Kinetics for the inhibition of acetylcholinesterase from the electric eel by some organophosphates and carbamates. Eur. J. Biochem. 140, 153-156.

18. Febbraio, F., D'Andrea, S. E., Mandrich, L., Merone, L., Rossi, M., Nucci, R. and Manco, G. (2008) Irreversible inhibition of the thermophilic esterase EST2 from Alicyclobacillus acidocaldarius. Extremophiles 12, 719-728.

19. Legler, P. M., Kumaran, D., Swaminathan, S., Studier, F. W. and Millard, C. B. (2008) Structural characterization and reversal of the natural organophosphate 
resistance of a D-type esterase, Saccharomyces cerevisiae S-formylglutathione hydrolase. Biochemistry 47, 9592-9601.

20. Degrassi, G., Kojic, M., Ljubijankic, G. and Venturi, V. (2000) The acetyl xylan esterase of Bacillus pumilus belongs to a family of esterases with broad substrate specificity. Microbiology 146, 1585-1591.

21. Leytus, S. P., Toledo, D. L. and Mangel, W. F. (1984) Theory and experimental method for determining individual kinetic constants of fast-acting, irreversible proteinase inhibitors. Biochim. Biophys. Acta 788, 74-86.

22. Tian, W. and Tsou, C. L. (1982) Determination of the rate constant of enzyme modification by measuring the substrate reaction in the presence of the modifier. Biochemistry 21, 1028-1032.

23. Liu, W. and Tsou, C. L. (1986) Determination of rate constants for the irreversible inhibition of acetylcholine esterase by continuously monitoring the substrate reaction in the presence of the inhibitor. Biochim. Biophys. Acta 870, 185-190.

24. Main, A. R. (1969) Kinetic evidence of multiple reversible cholinesterases based on inhibition by organophosphates. J. Biol. Chem. 244, 829-840.

25. Jancarik, J. and Kim, S. H. (1991) Sparse matrix sampling: a screening method for crystallization of proteins. J. Appl. Cryst. 24, 409-411.

26. CCP4 (1994) The CCP4 suite: programs for protein crystallography. Acta Crystallogr. D. Biol. Crystallogr. 50, 760-763.

27. Vagin, A. and Tepliakov, A. (1997) MOLREP: An automated program for molecular replacement. J. Appl. Cryst. 30, 1022-1025.

28. Emsley, P. and Cowtan, K. (2004) Coot: model-building tools for molecular graphics. Acta Crystallogr. D. Biol. Crystallogr. 60, 2126-2132.

29. Painter, J. and Merritt, E. A. (2006). Optimal description of a protein structure in terms of multiple groups undergoing TLS motion. Acta Crystallogr. D. Biol. Crystallogr. 62, 439-450.

30. Laskowski, R. A., MacArthur, M. W., Moss, D. S. and Thornton, J. M. (1993) PROCHECK: A program to check the stereochemical quality of protein structures. J. Appl. Cryst. 26, 283-291.

31. DeLano, W. L. (2002) The PyMOL Molecular Graphics System, DeLano Scientific, Palo Alto, CA, USA. http://pymol.sourceforge.net/

32. Bradford, M. M. (1976) A rapid and sensitive method for the quantification of microgram quantities of proteins utilizing the principle of protein-dye binding. Anal. Biochem. 72, 248-254.

33. Fernández-Murga, M. L., Gil-Ortiz, F., Llácer, J. L. and Rubio, V. (2004) Arginine biosynthesis in Thermotoga maritima. Characterization of the arginine-sensitive Nacetyl-L-glutamate kinase. J. Bacteriol. 186, 6142-6149.

34. Ileperuma, N. R., Marshall, S. D. G., Squire, C. J., Baker, H. M., Oakeshott, J. G, Russell, R. J., Plummer, K. M., Newcomb, R. D. and Baker, E. N. (2007) Highresolution crystal structure of plant carboxylesterase AeCXE1, from Actinidia eriantha, and its complex with a high affinity inhibitor paraoxon. Biochemistry 46, 1851-1859.

35. Politino, M., Tonzi, S. M., Burnett, W. V., Romancik, G. and Usher, J. J. (1997) Purification and characterization of a cephalosporin esterase from Rhodosporidium toruloides. Appl. Environ. Microbiol. 63, 4807-4811.

36. Degrassi, G., Kojic, M., Ljubijankic, G., and Venturi, V. (2000) The acetyl xylan esterase of Bacillus pumilus belongs to a family of esterases with broad substrate specificity. Microbiology 146, 1585-1591. 
37. Margolles-Clark, E., Tenkanen, M., Söderlund, H. and Penttilä, M. (1996) Acetyl Xylan Esterase from Trichoderma reesei contains an active-site serine residue and a cellulose-binding domain. Eur. J. Biochem. 237, 553-560.

38. Cummins, I., McAuley, K., Fordham-Skelton, A., Schwoerer, R., Steel, P. G., Davis, B. G. and Edwards, R. (2006) Unique regulation of the active site of the serine esterase S-formylglutathione hydrolase. J. Mol. Biol. 359, 422-432.

39. Mumpton, F. A. (1999). La roca magica: Uses of natural zeolites in agriculture and industry. Proc. Natl. Acad. Sci. U S A. 96, 3463-3470. 


\section{FIGURE LEGENDS}

Figure 1 Deacetylation reactions catalysed by AXE/CAHs. Substrates used include short xylooligosaccharides (A), cephalosporin C (B) or 7-amino cephalosporanic acid (C). $p$-Nitrophenyl acetate is also deacylated (D) and is used here to monitor the reaction.

Figure 2 Size and paraoxon inhibition of BpAXE. (A) Minimal number of steps for irreversible inhibition of an enzyme by a competitive inhibitor that modifies covalently the active centre. E, S, P, I, EI and EI* are enzyme, substrate, product, irreversible inhibitor, reversible complex and covalent complex with the inhibitor, respectively. (B) Size exclusion chromatography indicates that BpAXE is hexameric. Main graph, semilogarithmic plot of molecular mass versus elution volume [expressed as distribution coefficient, $K_{d}$ (see Experimental section)] of BpAXE (open square) and protein standards (in black). The molecular mass given for BpAXE is that deduced from the sequence, for a homohexamer. The standards used and their masses (in parentheses, in $\mathrm{kDa}$ ) are cytochrome c (12.4), carbonic anhydrase (29), bovine serum albumin (66.4), alcohol dehydrogenase (150), $\beta$-amylase (200), apoferritin (440), and thyroglobulin (669). The smaller panel proves that the elution position of BpAXE is independent of enzyme concentration, tested at concentrations of enzyme hexamers in the $100-\mu 1$ injection, of $35.9 \mu \mathrm{M}$ (top dotted line), $3.6 \mu \mathrm{M}$ (solid line) $0.36 \mu \mathrm{M}$ (broken line) 3.6 $\mathrm{nM}$ (open circles) and $1.8 \mathrm{nM}$ (open triangles). The top three lines correspond to optical absorption at $280 \mathrm{~nm}$. For the two smallest concentrations protein UV absorption was too small and thus the enzyme was detected by enzyme activity assays in fractions collected from the column. The results have been given in different scales to fit all of them in a single graph. The highest $\mathrm{OD}^{280}$ values for the 35.9, 3.6 and $0.36 \mu \mathrm{M}$ enzyme injections were, respectively, 0.944, 0.069 and 0.0036. Enzyme activity in the most active fraction for the injections of 3.6 and $1.8 \mathrm{nM}$ enzyme were, respectively, 0.010 and $0.006 \mathrm{U} \mathrm{ml}^{-1}$. (C) BpAXE inhibition kinetics by paraoxon. The main graph illustrates p-nitrophenol production (monitored as increase in absorbance at $405 \mathrm{~nm}$ ) at four paraoxon and enzyme concentrations (constant molar ratio of enzyme hexamer to paraoxon, $\left.1.18 \times 10^{-7}\right)$. Paraoxon concentrations for curves $\mathrm{a}, \mathrm{b}, \mathrm{c}$ and $\mathrm{d}$, were $6,4.5,3$ and $2 \mathrm{mM}$, respectively. The inset plots the value of the first-order constant for product accumulation, $\lambda$, obtained from curves such as a-d of the main graph, versus the paraoxon concentration. The hyperbola shown is that corresponding to $\lambda^{[\text {paraoxon] }=\infty}=\mathrm{k}_{\mathrm{i}}=$ $0.012 \mathrm{~s}^{-1}$ and a $\mathrm{K}_{\mathrm{I}}^{\text {app }}$ value of $5.4 \mathrm{mM}$. (D) Comparison of paraoxon-methyl, paraoxon and DFP as inhibitors of BpAXE. The main graph is as in C except for the use of 24.2 nM enzyme (as hexamers) and either $5 \mu \mathrm{M}$ paraoxon-methyl (curve a) $2 \mathrm{mM}$ paraoxon (curve b) and $20 \mathrm{mM}$ DFP (curve c). The inset plots the value of the first-order rate constant for product accumulation, $\lambda$, versus several paraoxon-methyl concentrations, at a constant molar ratio of the enzyme hexamer to this inhibitor of $4.84 \times 10^{-5}$. The hyperbola shown is that corresponding to $\lambda^{[\mathrm{DMP}]=\infty}=k_{i}=0.279 \mathrm{~s}^{-1}$ and a $\mathrm{K}_{\mathrm{I}}^{\text {app }}$ value of $13.4 \mu \mathrm{M}$.

Figure 3 BpAXE structure. The hexamer of BpAXE-DEP is viewed along the threefold axis in (A) and (B). (A) Cartoon representation, showing the bound DEP molecules in spheres. To highlight the trimer of dimers architecture, each dimer has its two subunits coloured in different hues of red, green or blue. In (B) a surface representation is shown with one trimer pink and semitransparent and the other yellow. DEP molecules are shown in spheres, across the subunits, in the internal cavity, and the 3-helix bundles of the upper trimer are illustrated as red ribbons, to highlight the 
paramount role of this bundle in subunit-subunit interactions. (C) $\mathrm{C} \alpha$ trace of one subunit (subunit A) in a projection that presents the $\alpha / \beta$ hydrolase fold close to the viewer (in red), showing in the background the N-terminal extension (in blue), and the 3-helix bundle (in green and labelled) that are characteristic of AXEs. The chain N-and C-ends are labelled. (D) Section of the BpAXE-DEP hexamer to highlight the internal chamber. The threefold axis is vertical and parallel to the page. Two DEP molecules are viewed within the chamber, and their surfaces are coloured red.

Figure 4 The active centre. (A) Substrate gorge (in semi-transparent surface representation) with one bound DEP molecule covalently bound to $S^{181}$. The other two residues of the catalytic triad, $\mathrm{H}^{298}$ and $\mathrm{D}^{269}$, as well as $\mathrm{Arg}^{87}$ and Gly ${ }^{98}$ (see text) are shown also in sticks representation. (B) Stereoview of the electron density map around the bound DEP molecule (subunit E). Relevant residues are shown. The $2 F_{o}-F_{c}$ electron density map contoured at $1.0 \sigma$ is shown as a blue grid, and, superimposed on it, the $F_{o^{-}}$ $F_{c}$ omit electron density map for DEP, contoured at $2.5 \sigma$ is illustrated as a red grid. The sticks model is coloured in light gray and yellow for carbon atoms of the protein and the ligand, respectively. Phosphorus, sulphur, nitrogen and oxygen atoms are green, orange, blue and red, respectively. Two hydrogen bonds of DEP with the protein are illustrated with dotted red lines. (C) and (D): Stereoviews (sticks representation) of (C) the superimposition of the DEP molecule and surrounding residues of BpAXE subunit E (in colour) and of carboxylesterase AeCX1 of A. eriantha (in light gray); and (D) of the active sites of one BpAXE subunit in the presence or in the absence of DEP.

Figure 5 Substrate binding and lack of corresponding conformational changes in BpAXE. Panels A-C compare the active centres (in semitransparent surface representation) of (A) S-formylglutathione hydrolase from Saccharomyces cerevisiae, (B) BpAXE and (C) the carboxylesterase 1 from Actinida eriantha (AeCX1). The acyl groups known to be cleaved by these enzymes (formate, acetate and butyrate in panels $\mathrm{A}, \mathrm{B}$ and $\mathrm{C}$, respectively) are modelled and shown in spheres representation in the substrate gorge of these enzymes, highlighting the very good complementarity with the site and explaining the acyl group specificity of each of these enzymes. Visible amino acid side chains involved in defining the pocket for the acyl group are shown in sticks. (D) Different positions of bound DEP in subunits A (in grey) and E (coloured) of BpAXE. In both subunits the changes affect only the binding of DEP, without substantial change in the positions of protein groups around bound DEP. Dashed lines represent hydrogen bonds. (E) Superimposition of the $\mathrm{C} \alpha$ trace for the hexamers of BpAXE-DEP (in black) and BpAXE-apo (in green). 
Table 1 Data collection and refinement statistics*

\begin{tabular}{|c|c|c|}
\hline & Native & $\begin{array}{l}\text { Crystallized with } \\
\text { paraoxon }\end{array}$ \\
\hline Parameter & \multicolumn{2}{|c|}{ Data Collection } \\
\hline Beamline & ID23-1 (ESRF) & BM16 (ESRF) \\
\hline Wavelength $(\AA)$ & 0.9789 & 0.9070 \\
\hline Space group & $P 2_{1}$ & $P 2_{1}$ \\
\hline $\begin{array}{l}\text { Unit cell a, b, c }(\AA) ; \\
\qquad \alpha, \beta, \gamma(\operatorname{deg})\end{array}$ & $\begin{array}{c}143.5,87.3,184.3 \\
90,112.9,90\end{array}$ & $\begin{array}{l}82.0116 .1100 .2 \\
\quad 90,105.6,90\end{array}$ \\
\hline $\begin{array}{l}\text { Resolution range }(\AA) \\
\quad \text { (Highest resolution shell) }\end{array}$ & $\begin{array}{l}29.60-1.90 \\
(2.00-1.90)\end{array}$ & $\begin{array}{l}116.2-2.70 \\
(2.85-2.70)\end{array}$ \\
\hline Reflections (Total/ Unique) & $1409349 / 304261$ & $199859 / 49317$ \\
\hline$I / \sigma_{I}$ & $6.0(2.0)$ & $7.1(1.8)$ \\
\hline $\mathrm{R}_{\mathrm{sym}} \dagger(\%)$ & $9.3(25.4)$ & $9.9(42.1)$ \\
\hline Completeness $(\%)$ & $85.2(92.2)$ & $99.5(99.6)$ \\
\hline Parameter & Refiner & ment \\
\hline Resolution range $(\AA)$ & $30.0-1.90$ & $20.0-2.70$ \\
\hline Reflections (work/test) & $288931 / 15312$ & $46958 / 2507$ \\
\hline $\mathrm{R}$ factor + (work/test) (\%) & $13.6 / 15.0$ & $21.6 / 23.6$ \\
\hline \multicolumn{3}{|l|}{ Average B-factors $\left(\AA^{2}\right)$} \\
\hline Protein atoms & 13.40 & 20.67 \\
\hline DEP & - & 58.20 \\
\hline Water & 8.50 & 11.72 \\
\hline \multicolumn{3}{|l|}{ Number of: } \\
\hline Polypeptide chains & 12 & 6 \\
\hline Protein atoms & 30050 & 14502 \\
\hline DEP molecules & & 6 \\
\hline Water molecules & 1505 & 41 \\
\hline RMSD bond $(\AA)$ & 0.015 & 0.003 \\
\hline RMSD angle $\left(^{\circ}\right)$ & 1.34 & 0.64 \\
\hline \multicolumn{3}{|l|}{ Ramachandran plot $\S$} \\
\hline Most favored $(\%)$ & 90.5 & 88.4 \\
\hline Additional allowed (\%) & 8.8 & 10.8 \\
\hline Generously allowed (\%) & 0.7 & 0.4 \\
\hline Disallowed (\%) & 0.0 & 0.4 \\
\hline
\end{tabular}

${ }^{*}$ Values in parenthesis are data for the highest resolution shell.

$\dagger \mathrm{R}_{\text {sym }}=\Sigma|\mathrm{I}-<\mathrm{I}>| / \Sigma \mathrm{I}$, where I is the observed intensity, and $<\mathrm{I}>$ is the average intensity of multiple observations of symmetry-related reflections.

$\ddagger \mathrm{R}$ factor $=\Sigma_{\mathrm{hkl}}|| \mathrm{F}_{\text {obs }}|-| \mathrm{F}_{\text {calc }}|| / \Sigma_{\mathrm{hkl}}\left|\mathrm{F}_{\mathrm{obs}}\right|$, where $\mathrm{F}_{\mathrm{obs}}$ and $\mathrm{F}_{\text {calc }}$ are the observated and calculated structure factors, respectively.

$\S$ Calculated using PROCHECK. 
A

B
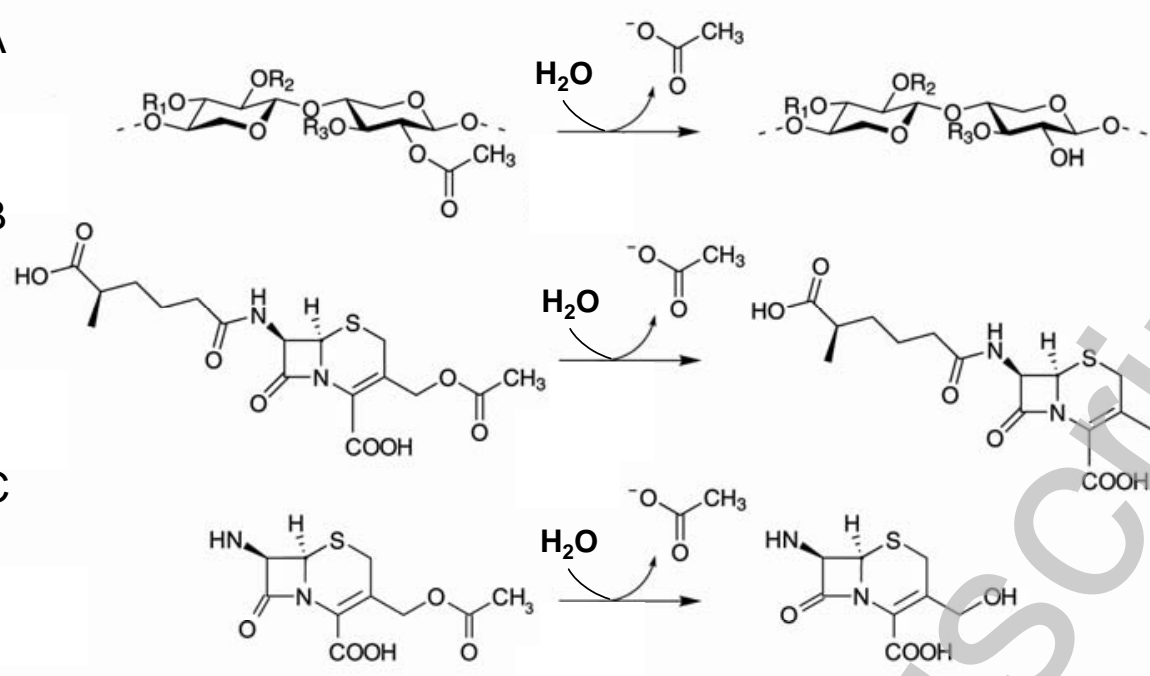

D

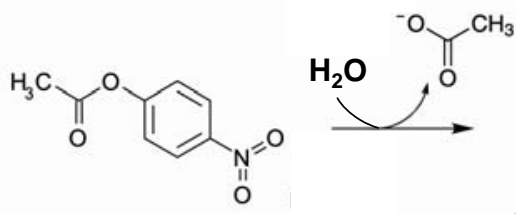

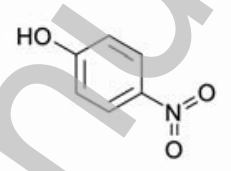

Figure 1 

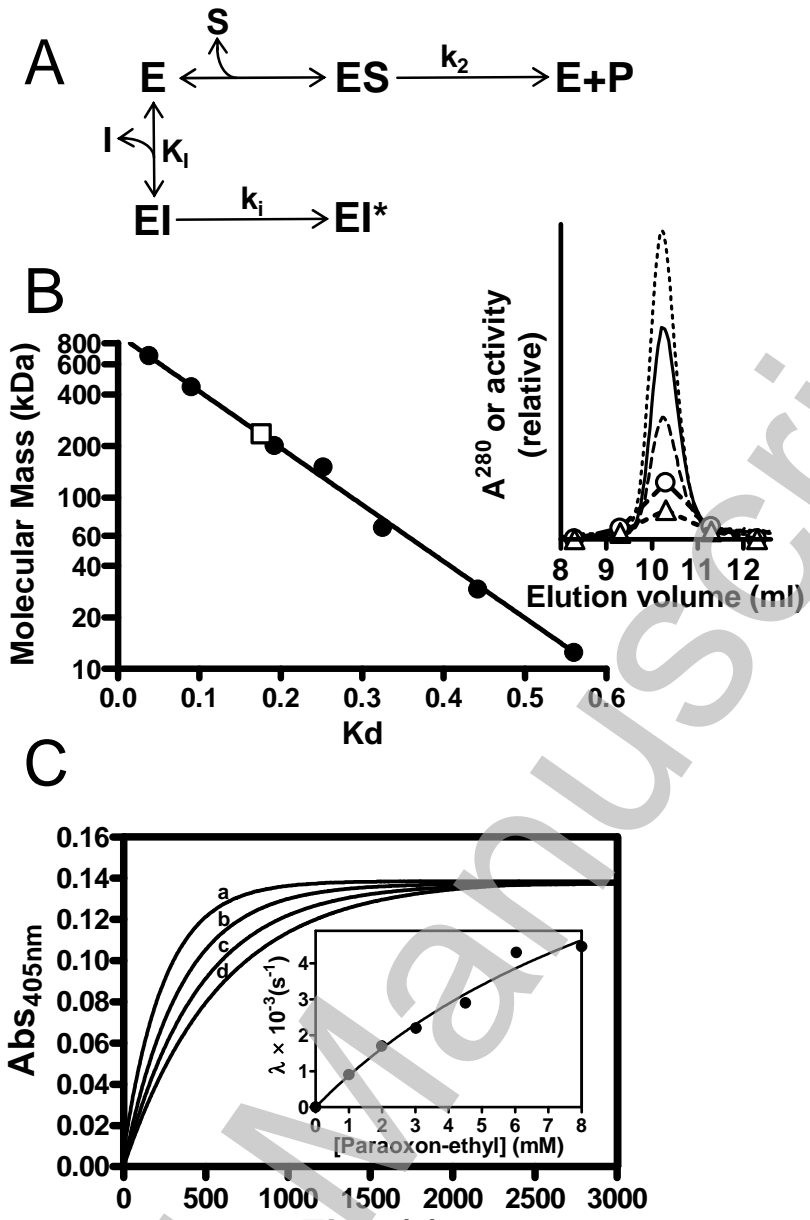

D Time (s)

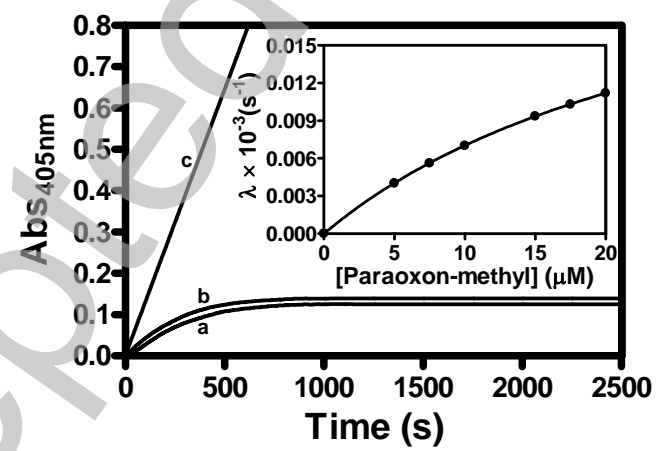

Figure 2

Licenced copy. Copying is not permitted, except with prior permission and as allowed by law. (C) 2011 The Authors Journal compilation (c) 2011 Portland Press Limited 
Biochemical Journal Immediate Publication. Published on 07 Mar 2011 as manuscript BJ20101859
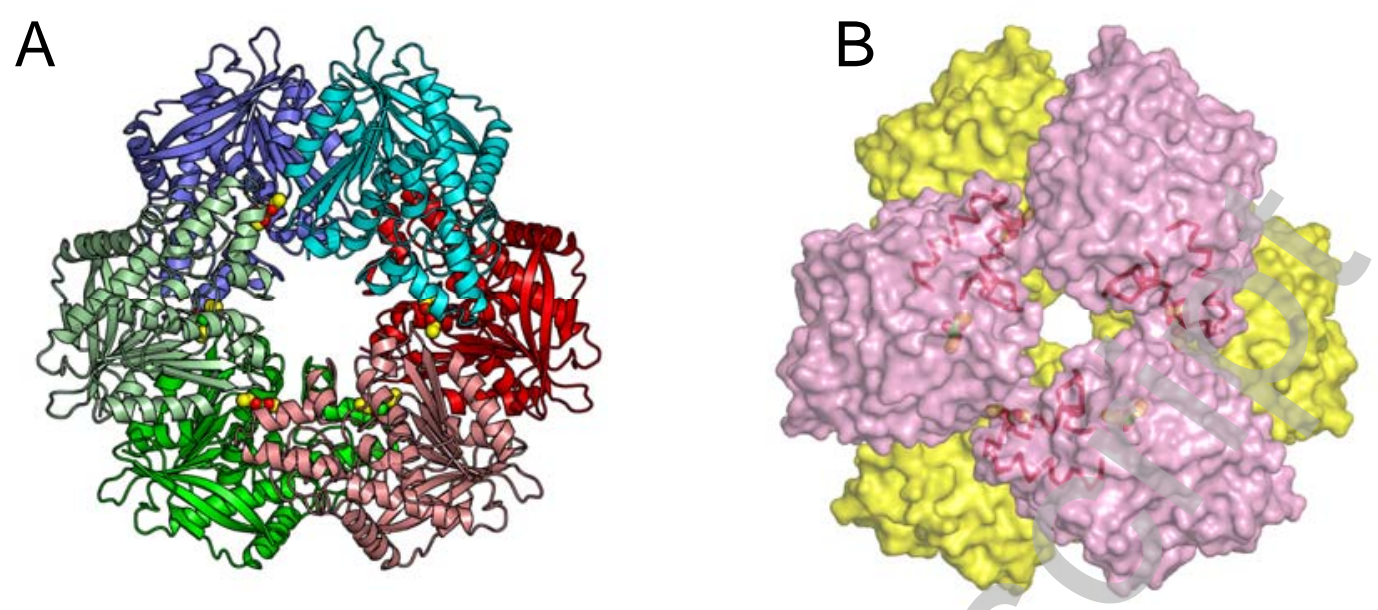

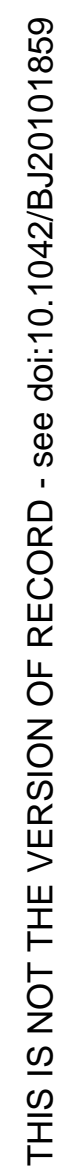

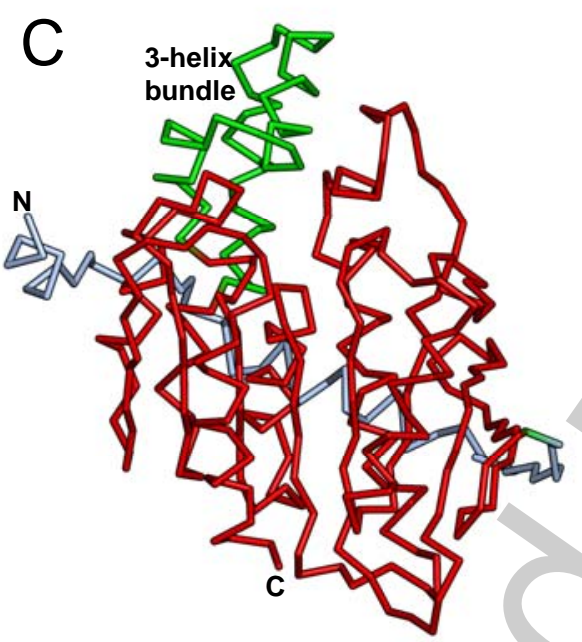

$\mathrm{D}$

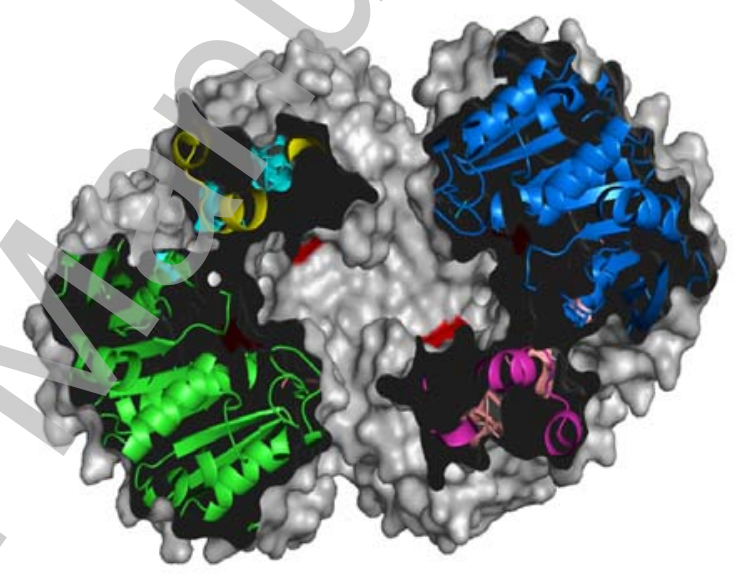

Figure 3

Licenced copy. Copying is not permitted, except with prior permission and as allowed by law. (C) 2011 The Authors Journal compilation (c) 2011 Portland Press Limited 

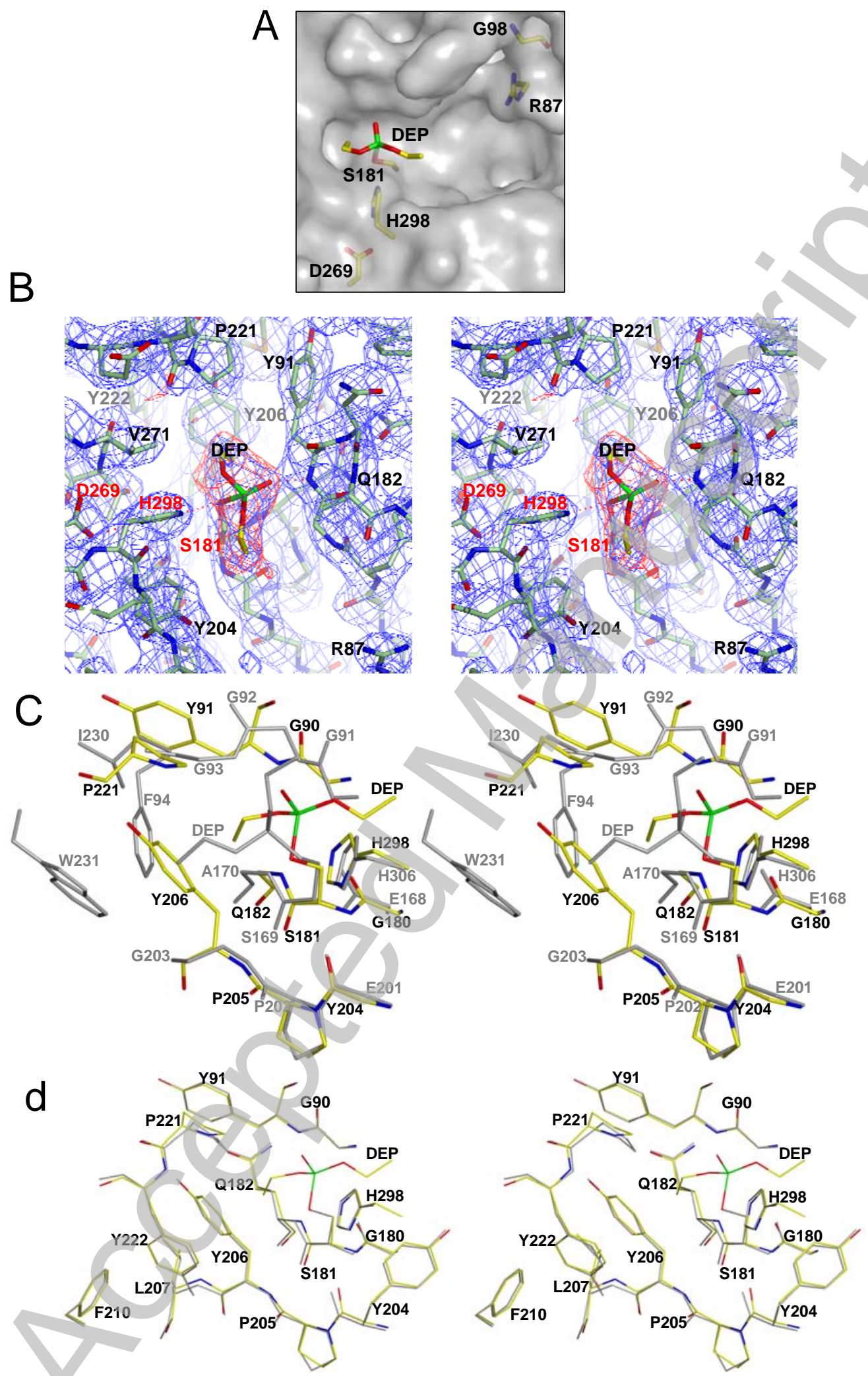

Figure 4 


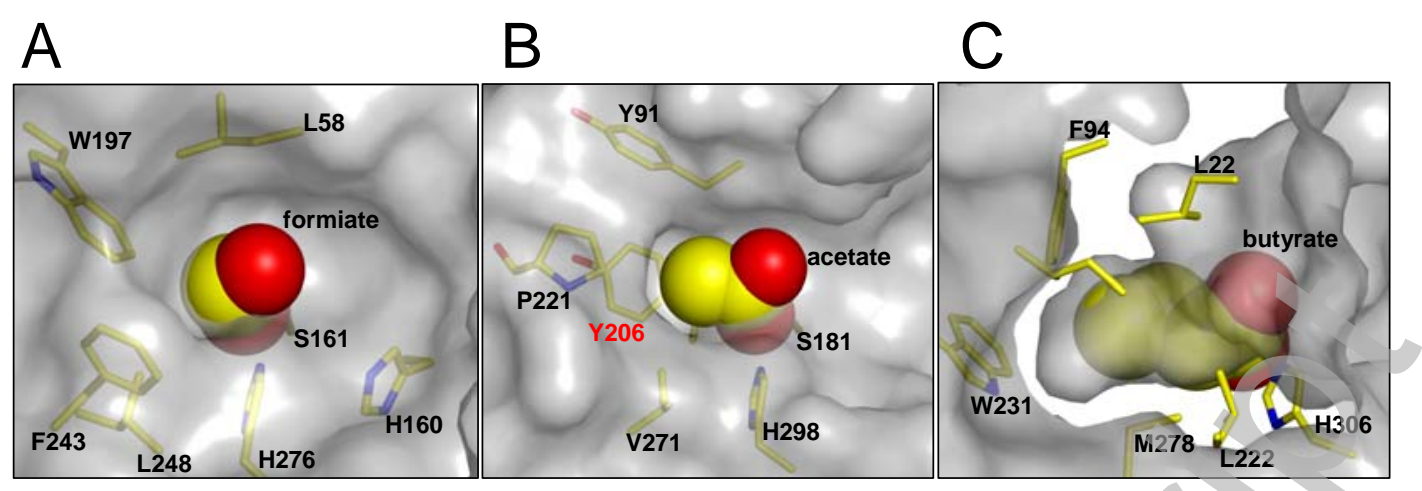

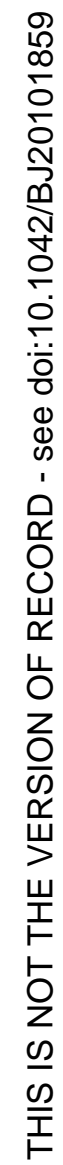

D

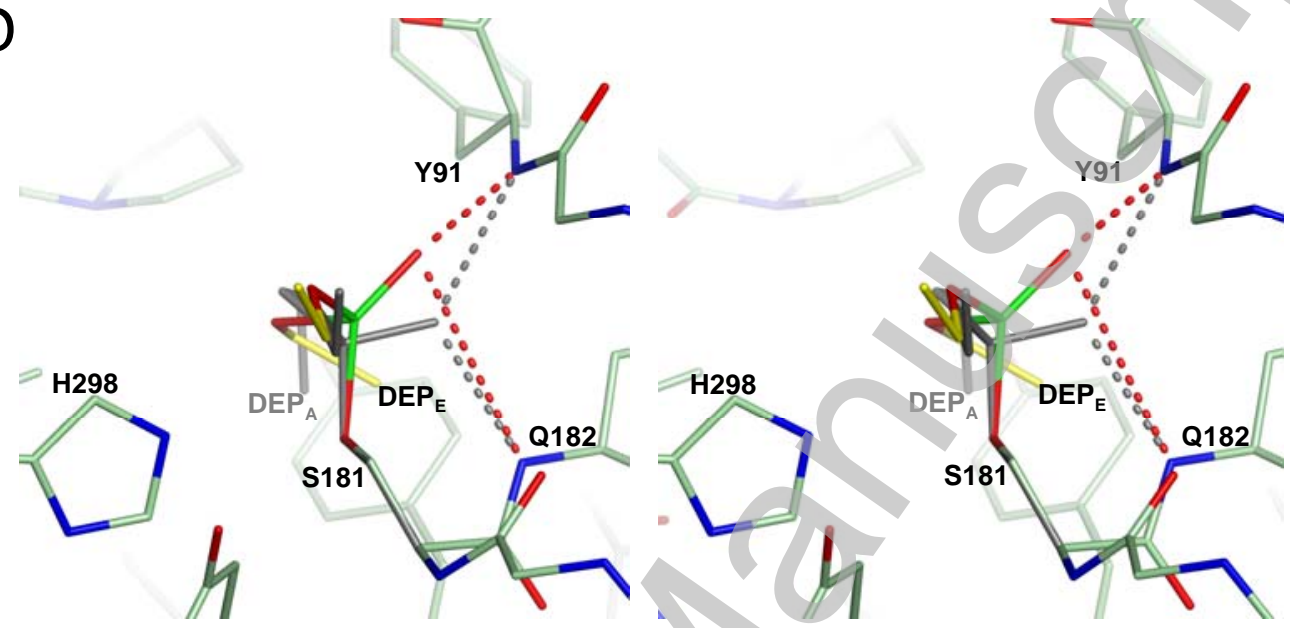

E
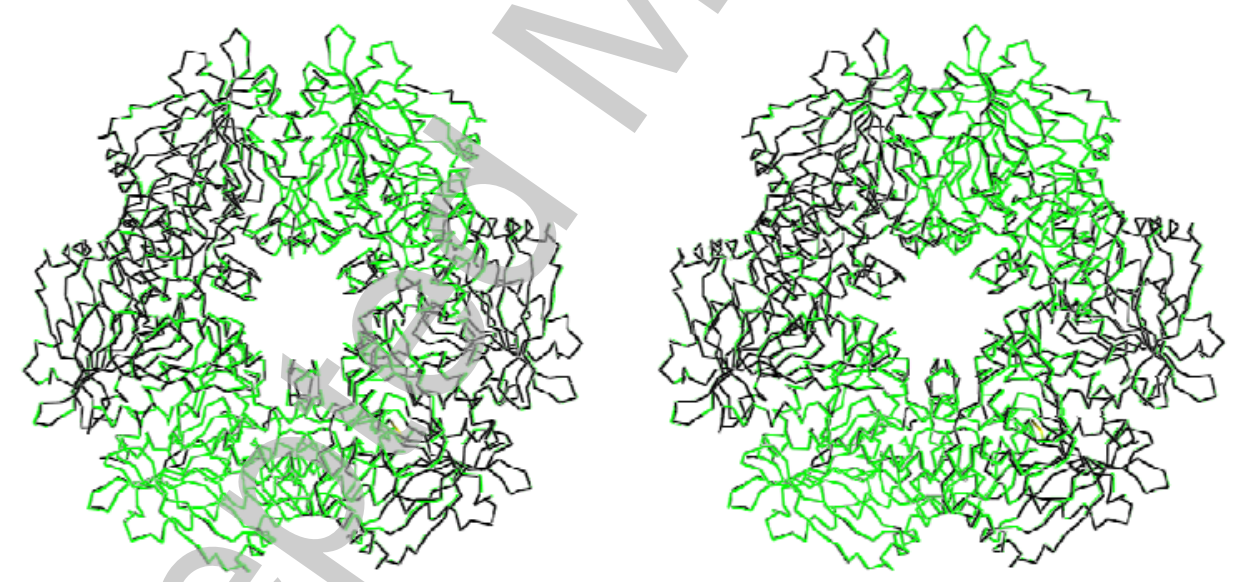

Figure 5 